\title{
Agenesis of the corpus callosum and voluntary wheel running in mice
}

\author{
KATHERINE M. BISHOP, ANNALEE KRUYER, and DOUGLAS WAHLSTEN \\ University of Alberta, Edmonton, Alberta, Canada
}

\begin{abstract}
Humans born without a corpus callosum (CC) are often comparatively slow and clumsy on tasks requiring bilateral motor coordination. In this study, we attempted to identify correlates of CC agenesis in mice by examining an ecologically valid motor behavior: running-wheel performance. Mice with varying degrees of congenital CC deficits were tested on a running wheel apparatus for 7 consecutive days. The mice became more proficient at running with experience (i.e., rotations, time spent running, length of running bouts, and maximum and modal running speeds increased while variability of rotation times decreased). Multiple regression analysis suggested that CC deficiency may be related to 2 out of 20 measurements of running (decreased variability of rotation times and shorter maximum running bout duration), but at levels below the traditional criteria for significance. Although these variables predicted CC deficiency at a level significantly greater than chance (71\% correct) in a discriminant analysis, examination of the meaning of their relationship with CC size suggested that any connection may be spurious.
\end{abstract}

Axons of the corpus callosum (CC) connect the cerebral hemispheres in placental mammals. Agenesis of the $\mathrm{CC}$ occurs in the embryo when axons are unable to cross the cerebral midline but instead grow longitudinally in the novel Probst bundle (Ozaki, Murakami, Toyoshima, \& Shimada, 1987; Ozaki \& Shimada, 1988) and soon return to the ipsilateral cerebral cortex (Ozaki \& Wahlsten, 1993). In humans, the incidence of callosal agenesis is estimated to be $0.0005 \%-0.7 \%$ (Wisniewski \& Jeret, 1994), and its occurrence is often associated with other neurological deficits (Aicardi \& Chevrie, 1994; Andermann \& Andermann, 1994). It is paradoxical that humans born without a $\mathrm{CC}$ exhibit comparatively few behavioral or performance deficits, especially in comparison with patients who have had their CC surgically split (Sauerwein \& Lassonde, 1994; Sperry, 1982). Unlike callosotomy patients, acallosals can transfer information from one hemisphere to another, suggesting that plasticity exists in the formation of forebrain cortical connections. The most consistent functional finding is that acallosals often exhibit deficits on motor tasks requiring bimanual coordination, especially under speed stress (Silver \& Jeeves, 1994).

Four strains of mice (BALB/c, I/LnJ, 129, and ddN) frequently exhibit congenital agenesis of the $\mathrm{CC}$ to vary-

The authors are grateful to Violet Sparks for assistance with breeding the mice, Tracy Malenfant for animal care, and Jonathan Sparks for help with the histology. This work was supported in part by Grant OGP 45825 from the Natural Sciences and Engineering Research Council of Canada and an NSERC scholarship to K.M.B. A.K. is now at the Department of Psychology, University of Western Ontario, London, ON. Address all correspondence to D. Wahlsten, Department of Psychology, University of Alberta, Edmonton, AB, Canada T6G 2E9 (e-mail: wahlsten@psych.ualberta.ca). ing degrees. Several recent studies utilizing the transgenic knockout method in mice have also reported a high frequency of absent CC (Müller et al., 1994; Qiu, Anderson, Meneses, Pedersen, \& Rubenstein, 1995; Stumpo, Bock, Tuttle, \& Blackshear, 1995). However, the 129/SvJ substrain is widely utilized as the source of embryonic stem cells in this method, and there is uncertainty about whether the targeted genes or additional portions of the 129 genome are responsible for the acallosal phenotype. Much is known about the anatomical and genetic etiology of CC agenesis in mice (Wahlsten \& Ozaki, 1994). Tests of bilateral motor coordination suggest subtle problems in limb coordination. I/Ln mice, which always exhibit complete $\mathrm{CC}$ agenesis, have been observed circling during swimming navigation (Lipp \& Waanders, 1990; Lipp \& Wahlsten, 1992). I/Ln animals are known for their high activity (McClearn, Wilson, \& Meredith, 1970 ), and fast moving animals often show bouts of uncontrolled circling which alternate with straight running. On a task requiring mice to walk along a notched bar, a clear strain correlation was found between size of the CC and the number of hind-paw slips, the acallosal $1 /$ Ln mice having the greatest mean number of slips (Lipp \& Wahlsten, 1992). However, no correlation between CC size and platform slips was observed within strains $[129 / \mathrm{J}$, $\mathrm{BALB} / \mathrm{c},(\mathrm{C} 57 \mathrm{BL} / 6 \times \mathrm{I} / \mathrm{Ln}) \times \mathrm{I} / \mathrm{Ln}$ backcrosses].

Completely acallosal I/Ln mice are relatively ambilateral in comparison with strains with normal CCs and strong paw preferences (Gruber, Waanders, Collins, Wolfer, \& Lipp, 1991). However, in a sample of backcrossed hybrids $[(\mathrm{C} 57 \mathrm{BL} / 6 \times \mathrm{I} / \mathrm{Ln}) \times \mathrm{I} / \mathrm{Ln}]$ no correlation between $\mathrm{CC}$ size and degree of paw lateralization was observed (Lipp, Bechel, Wolfer, \& Scheffran, 1991). Although a significant correlation was reported in a small sample of $129 / \mathrm{J}$ mice but not in a sample of BALB/c 
mice (Ward, Tremblay, \& Lassonde, 1987), larger studies have confirmed the lack of relationship between $\mathrm{CC}$ size and degree of paw preference lateralization in BALB/c mice (Bulman-Fleming, Wainwright, \& Collins, 1992; Schmidt, Manhães, \& de Moráes, 1991).

In the present study, we assessed the impact of CC agenesis on mouse running-wheel performance, a task involving high-speed running and relying on the intrinsic motivation of mice to run. Wheel running was examined in mice obtained by inbreeding different family lines from an $F_{2}$ cross between BALB/cWahl and 129/ ReJ (Wahlsten \& Sparks, 1995). This method yielded many animals with total absence of the $\mathrm{CC}$. It was hypothesized that mice with absent $\mathrm{CC}$ would run more slowly and clumsily (i.e., stumble more often at high speeds) than mice with an intact $\mathrm{CC}$, because the acallosal mice rely on indirect cortical pathways with lower speed and capacity for transmitting information between the hemispheres.

\section{METHOD}

\section{Subjects}

The subjects were 42 mice from 16 recombinant inbred (RI) lines made and maintained in the laboratory (Wahlsten \& Sparks, 1995). These lines were chosen haphazardly from a larger set of 48. Between 1 and 5 mice from only one or two litters were used from any one strain. The lines were generated from hybrid crosses of either a $129 / \mathrm{ReJ}$ female $\times \mathrm{BALB} / \mathrm{cWah} 1$ male or a BALB/ cWahl female $\times 129 /$ ReJ male. In the $F_{2}$ generation, pairs of parents were chosen randomly, and their offspring were then inbred by full-sib mating. Mice in this study were from generations two to five of inbreeding, and they were not yet highly inbred. In fact, 10 of the 16 RI lines were highly variable phenotypically, only 1 consistently showed total CC absence, and 5 consistently showed normal CCs. For the variable RI lines, acallosal and normal mice were often found in the same litter, which rendered a litter-means analysis inappropriate. By sampling mice from so many gradually diverging strains, the probability of spurious genetic correlations of behavior with absence of the $\mathrm{CC}$ was rendered very low. Breeding was performed by randomly selecting 1 male and 1 female from an RI line and placing them together in a standard $(29 \times$ $18 \times 13 \mathrm{~cm}$ ) plastic mouse cage. At mating and throughout pregnancy and lactation, the parent mice were fed freely with high fat Wayne Mouse Breeder Blox 8626 and given free access to Edmonton tap water. The cage contained Aspen Chip bedding and one compacted paper "Nestlet" for nest construction. The pups were weaned and housed in groups of same-sex littermates at 20-22 days after birth, and they received the standard, low-fat diet (Wayne Rodent Blox 8604). All mice were housed in a temperaturecontrolled room with a dark-cycle of $6: 00 \mathrm{p} . \mathrm{m}$. to $6: 00 \mathrm{a} . \mathrm{m}$. The mice were tested at 8 weeks of age, except for 4 mice which were tested at 102 days.

\section{Apparatus and Task}

The test apparatus has been described in detail elsewhere (Wahlsten, Bishop, \& Kruyer, in press). It consisted of an aluminum wheel (radius $=10.0 \mathrm{~cm}$ ) mounted on one inner wall of a $32.0 \times 32.0 \mathrm{~cm}$ Acrylite box with $30.5-\mathrm{cm}$-high walls. A $15.0 \times$ $12.5 \times 10.5 \mathrm{~cm}$ opaque nest box was attached to the outer side of the opposite wall of the wheel box with a hole (diameter = $4.5 \mathrm{~cm}$ ) connecting the nest and wheel boxes. The nest box contained Aspen chip bedding, three pieces of Kleenex for nestbuilding, a water bottle, and food. The mouse was free to travel between the nest box and wheel box at all times. The running wheel had forty-four $5.0-\mathrm{cm}$-long round stainless steel bars (diameter $=1.0 \mathrm{~mm}$ ) spaced $1.0 \mathrm{~cm}$ apart around its circumference and was attached to the box wall by a steel shaft. On the outside of the box, the wheel was attached to a black disk (diameter = $12.0 \mathrm{~cm}$ ) holding three reflective strips each covering $20^{\circ}$ of arc placed $120^{\circ}$ apart, one on each of an inner, middle, and outer track. Three photocells attached to the disk detected the strips when the wheel was turned, allowing for the detection of partial turns. The drag on the wheels was controlled by a compression device that altered the friction on the shaft and thereby altered the amount of work required to turn the wheel. Programs written in the $C$ language were used to calibrate the drag of the wheel and ensure that the photocells were working before mouse wheel running was monitored. Four running wheels were connected to a 486-DX33 computer via an interface circuit which transmitted a continuous $5-\mathrm{V}$ signal to the computer when the photocell was over a strip. Running was defined as the consecutive detection of two different strips. The criterion for cessation of running was set at $0.75 \mathrm{sec}$ for $1 / 3$ rotation on the basis of statistical analysis and time-lapse video recordings, and a period of at least $0.75 \mathrm{sec}$ without hitting a new strip marked the start and end of a bout of running. A C program simultaneously monitored the four wheels and, for each wheel, calculated number of $1 / 3$ rotations and cumulative time spent running. When the same reflective strip was sensed twice in a row, a "swing" was counted. The program also calculated minimum rotation time (maximum speed), mode of rotation times, and variability of rotation times within a bout (the average squared difference between times for consecutive thirds of a rotation). Note that mice that stumble more often should show larger

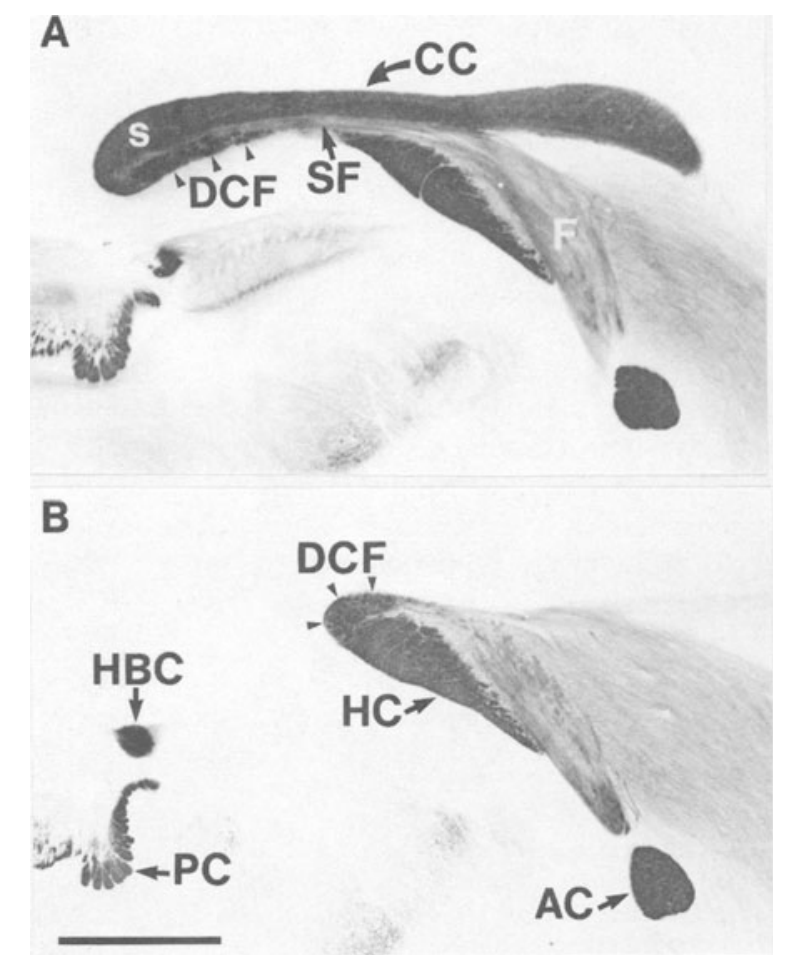

Figure 1. Midsagittal sections showing myelinated fibre tracts. The corpus callosum (CC), splenium of the corpus callosum (S), fornix (F), dorsal commissures of the fornix (DCF), superior fornix (SF), hippocampal commissure (HC), anterior commissure (AC), posterior commissure (PC), and habenular commissure (HBC) are labeled. (A) Example of a normal mouse (RI line 44, 59 days old). (B) An acallosal mouse (RI line 16, 57 days old) in which the $C C$ is absent. Scale bar $=1.0 \mathrm{~mm}$. 
differences between sequential times. Because mice run in bouts of activity separated by periods of rest, a frequency distribution of the duration of running bouts was calculated, and bouts less than $1 \mathrm{sec}$ in duration (only two strips crossed), bouts from 1 to $10 \mathrm{sec}$, and bouts greater than $10 \mathrm{sec}$ were counted.

\section{Procedure}

Before proceeding, we estimated the number of mice required in order to yield reasonably high power. If the reliabilities of the neural and behavioral measurements are known and a plausible estimate of the true brain-behavior correlation can be made, the expected value of the brain-behavior correlation and the sample size required in order to detect this correlation can be easily calculated (Wahlsten, 1992). Running-wheel behavior is probably a reflection of several neural processes. A linear model was posited in which CC size was hypothesized to account for about $25 \%$ of the true neural variability in wheel running. Behavioral reliability (Cronbach's $\alpha=.83$ ) was calculated from a 3-day pilot test of mouse wheel running and interobserver correlation for measurement of CC size was $r=.99$. Using these estimates, the expected phenotypic correlation between CC size and wheel running was calculated to be .45 (Wahlsten, 1992), and approximately 35 subjects would be required in order to yield a test with $80 \%$ power if two-tailed tests were done with Type I error probability of .05 (Kraemer \& Thiemann, 1987). This method assumes that the neural and behavioral measures are normally distributed. In this sample, the distribution of $\mathrm{CC}$ sizes was bimodal, and therefore the power was actually greater than $80 \%$.

Mice were randomly selected from an age-appropriate cohort and randomly assigned to one of four computer-monitored running wheels. The drag of the wheels was set to -3 radians $/ \mathrm{sec}^{2}$, a level at which the mice ran without too much effort but at which the wheel did not continue to turn more than $1 / 3$ rotation after a mouse had jumped off (Wahlsten et al., in press). The mice were left in the wheel apparatus for 7 consecutive days and their running behaviors monitored for $20 \mathrm{~h}$ each night $(3: 30 \mathrm{p} . \mathrm{m}$. to 11:30 a.m.; lights off at 6:00 p.m. and on at 6:00 a.m.). Food and water were provided ad lib and checked each day at 12:00 p.m. Because the mice exhibited no obvious outward signs of agenesis of the $\mathrm{CC}$, at the time of testing the experimenters did not know the CC size of the mice. Within $24 \mathrm{~h}$ of the end of the test period, each mouse was weighed, anaesthetized with a pentobarbital overdose $(120 \mathrm{mg} / \mathrm{kg})$, and perfused intracardially with $10-15 \mathrm{ml}$ of saline vascular rinse followed by $20-30 \mathrm{ml}$ of neutral $4 \%$ paraformaldehyde in $0.1 \mathrm{M}$ phosphate buffer. The brains were ex- tracted from the skull and placed in fresh fixative for 1 week, blocked to a standard configuration (Wahlsten, 1984), blotted, weighed, and bisected sagittaly. The left half of each brain was stained en bloc using gold chloride (Schmued, 1990), and the areas of the $\mathrm{CC}$ and hippocampal commissure (HC) were measured with the JAVA video analysis system from Jandel Scientific. Care was taken not to include either the superior fornix or the dorsal commissure of the fornix in the measurement of the $\mathrm{CC}$ (see Figure 1A). Two-tailed tests were used in the statistical analyses, because in some cases the direction of the expected effect was not known a priori.

\section{RESULTS}

Of the 42 mice tested, 7 did not run on one or more days ( 3 mice did not run 1 day, 2 on 2 days, and 2 on 5 days). Running and non-running mice did not differ in sex, or in body, brain, CC, or HC size ( $t$ tests, $p s>.05$ ). Because of problems in calculating statistics with missing data, the non-running mice were eliminated from the analysis. Plots of $\mathrm{CC}$ size against the running variables identified one case that appeared to be an extreme outlier. This mouse ran very little and had no CC. Preliminary regression analyses and examination of the regression diagnostics confirmed that this mouse was an outlier (Studentized $T=-4.17, p<.001$ ) and that it had a large degree of influence on the regression results (Cook's distance $=0.435$ ). Consequently, this case was omitted from all analyses, leaving a sample size of 34 mice.

Table 1 shows the means and standard deviations of running-wheel variables over the 7 days of testing. Repeated measures analyses of variance (ANOVAs) assessing the effects of day revealed significant effects for all measurements except bouts less than $1 \mathrm{sec}$ in duration. However, these extremely short bouts involved playing with the wheel (i.e., jumping on and off) rather than true running. All measurements changed in the direction expected with increased running proficiency (rotations, time running, and bout lengths increased while rotation times and variability of rotation times decreased). The

Table 1

Repeated Measures Analysis of the Effect of Days of Repeated Testing of 34 Mice on Running Wheel Measurements Showing the Mean $S D$ for Each Day

\begin{tabular}{|c|c|c|c|c|c|c|c|c|c|c|c|c|c|c|c|c|c|}
\hline \multirow[b]{3}{*}{ Running Variable } & \multicolumn{14}{|c|}{ Day } & \multirow[b]{3}{*}{$F^{*}$} & \multirow[b]{3}{*}{$p^{\dagger}$} & \multirow[b]{3}{*}{$\alpha \ddagger$} \\
\hline & \multicolumn{2}{|c|}{1} & \multicolumn{2}{|r|}{2} & \multicolumn{2}{|c|}{3} & \multicolumn{2}{|l|}{4} & \multicolumn{2}{|c|}{5} & \multicolumn{2}{|c|}{6} & \multicolumn{2}{|l|}{7} & & & \\
\hline & $M$ & $S D$ & $M$ & $S D$ & $M$ & $S D$ & $M$ & $S D$ & $M$ & $S D$ & $M$ & $S D$ & $M$ & $S D$ & & & \\
\hline Rotations & 5,534 & 4,568 & 6,660 & 4,817 & 7,247 & 5,270 & 9,020 & 6,090 & 9,790 & 7,425 & 10,990 & 7,516 & 11,109 & 6,729 & 16.6 & .000 & .95 \\
\hline Swings & 2,357 & 1,534 & 2,166 & 1,765 & 1,565 & 646 & 1,656 & 965 & 1,570 & 912 & 1,958 & 1,278 & 2,007 & 1,475 & 3.3 & .004 & .83 \\
\hline Time running ( $\mathrm{min}$ ) & 104 & 80 & 119 & 79 & 123 & 79 & 150 & 89 & 156 & 99 & 169 & 99 & 169 & 88 & 11.0 & .000 & .95 \\
\hline $\begin{array}{l}\text { Minimum rotation time } \\
(\mathrm{msec} / 1 / 3 \text { rotation }) \\
\text { Mode of rotation times }\end{array}$ & 230 & 40 & 220 & 40 & 210 & 40 & 210 & 30 & 210 & 40 & 200 & 30 & 190 & 30 & 20.2 & .000 & .96 \\
\hline $\begin{array}{c}(\mathrm{msec} / 1 / 3 \text { rotation }) \\
\text { Variability of rotation }\end{array}$ & 340 & 80 & 310 & 50 & 300 & 60 & 290 & 50 & 290 & 50 & 270 & 50 & 270 & 50 & 21.5 & .000 & .95 \\
\hline times $\left(\mathrm{msec}^{2}\right)$ & 3,818 & 645 & 3,774 & 446 & 3,698 & 466 & 3,478 & 676 & 3,509 & 670 & 3,345 & 539 & 3,247 & 730 & 6.2 & .000 & .74 \\
\hline Bouts $<1 \mathrm{sec}$ & 2,502 & 1,638 & 2,459 & 1,847 & 2,188 & 1,730 & 2,149 & 1,691 & 2,082 & 1,789 & 2,484 & 2,350 & 2,302 & 1,839 & 0.7 & .660 & .90 \\
\hline Bouts $\mathrm{l}-10 \mathrm{sec}$ & 1,400 & 1,040 & 1,446 & 936 & 1,379 & 774 & 1,508 & 793 & 1,524 & 884 & 1,715 & 1,058 & 1,715 & 915 & 2.2 & .040 & .93 \\
\hline Bouts $>10 \mathrm{sec}$ & 58 & 91 & 87 & 121 & 121 & 154 & 159 & 169 & 175 & 187 & 175 & 165 & 180 & 168 & 7.9 & .000 & .90 \\
\hline Longest bout (sec) & 22 & 17 & 26 & 20 & 28 & 20 & 38 & 28 & 42 & 28 & 38 & 25 & 38 & 24 & 8.9 & .000 & .92 \\
\hline
\end{tabular}

*From repeated measures ANOVA with day as repeated factor. †Two-tailed $p$ values. $\quad \neq \alpha$ is Cronbach's alpha, a measure of test reliability, calculated over 7 days of testing. 
Table 2

Correlations (Pearson $r$, With Probabilities) Between Mean Measures of Running-Wheel Performance*

\begin{tabular}{|c|c|c|c|c|c|c|c|c|c|c|c|c|c|c|c|c|c|c|}
\hline & \multicolumn{2}{|c|}{$\begin{array}{c}\text { Time } \\
\text { Running }\end{array}$} & \multicolumn{2}{|c|}{ Swings } & \multicolumn{2}{|c|}{$\begin{array}{l}\text { Minimum } \\
\text { Rotation } \\
\text { Time }\end{array}$} & \multicolumn{2}{|c|}{$\begin{array}{l}\text { Modal } \\
\text { Rotation } \\
\text { Rime }\end{array}$} & \multicolumn{2}{|c|}{$\begin{array}{l}\text { Variance of } \\
\text { Rotation } \\
\text { Times }\end{array}$} & \multicolumn{2}{|c|}{$\begin{array}{l}\text { Bouts } \\
<1 \mathrm{sec}\end{array}$} & \multicolumn{2}{|c|}{$\begin{array}{l}\text { Bouts } \\
1-10 \mathrm{sec}\end{array}$} & \multicolumn{2}{|c|}{$\begin{array}{c}\text { Bouts } \\
>10 \mathrm{sec}\end{array}$} & \multicolumn{2}{|c|}{$\begin{array}{c}\text { Longest } \\
\text { Bout }\end{array}$} \\
\hline & $r$ & $p$ & $r$ & $p$ & $r$ & $p$ & $r$ & $p$ & $r$ & $p$ & $r$ & $p$ & $r$ & $p$ & $r$ & $p$ & $r$ & $p$ \\
\hline Rotations & .98 & .00 & .54 & .00 & -.68 & .00 & -.62 & .00 & -.50 & .00 & .20 & .26 & .85 & .00 & .84 & .00 & .42 & .01 \\
\hline Time running & & & .49 & .00 & -.61 & .00 & -.52 & .00 & -.42 & .01 & .24 & .17 & .87 & .00 & .85 & .00 & .42 & .01 \\
\hline Swings & & & & & -.58 & .00 & -.60 & .00 & -.31 & .07 & .54 & .00 & .58 & .00 & .20 & .29 & .26 & .13 \\
\hline Minimum rotation time & & & & & & & .93 & .00 & .55 & .00 & -.24 & .17 & -.59 & .00 & -.44 & .01 & -.36 & .04 \\
\hline Modal rotation time & & & & & & & & & .47 & .01 & -.28 & .11 & -.55 & .00 & -.31 & .07 & -.29 & .10 \\
\hline Variability of rotation times & & & & & & & & & & & .16 & .36 & -.30 & .09 & -.47 & .01 & -.34 & .05 \\
\hline Bouts & & & & & & & & & & & & & .43 & .01 & -.17 & .33 & -.12 & .50 \\
\hline $\mathrm{sec}$ & & & & & & & & & & & & & & & .49 & .00 & .17 & .33 \\
\hline Bouts $>10$ sec & & & & & & & & & & & & & & & & & .57 & .00 \\
\hline
\end{tabular}

*Two-tailed $p$ values.

change over days was best described by a linear function for all measurements except swings, which fit a quadratic function most closely. Reliabilities of running measurements over the 7 days were calculated with Cronbach's $\alpha$ (Wahlsten, 1992) and were found to be acceptably high (see Table 1). In summary, the variables examined in this study were reliable measures of mouse running-wheel activity and indicated that mice significantly improved their running performance with increased practice on the wheel apparatus. These high reliabilities meant not only that performance of an individual mouse was very consistent from one day to the next but also that differences between individual mice were quite large.

In order to examine the relationship between measures of running-wheel performance across mice, Pearson correlations between wheel variables were calculated using the mean values over days (see Table 2). The running behavior reliabilities were not upper limits on the correlations between variables, because the correlations depended on the mean values over days while the reliabilites were calculated using data from all days. Number of rotations and time spent running appeared to be measures of overall level of activity, correlating strongly with each other $(r=.98)$ and to some degree with most of the other variables in the direction expected. The minimum and modal rotation times were highly correlated $(r=.93)$, indicating that mice that generally ran faster also had a higher peak speed. Variability of rotation times, thought to be an indicator of slips on the wheel, was correlated with minimum $(r=.55)$ and modal $(r=$ .47) rotation times, indicating that mice that generally ran slower also slipped more often. The number of bouts less than $1 \mathrm{sec}$ in duration was correlated most strongly with swings $(r=.57)$, suggesting that both of these variables were measures of playing rather than running. The number of true running bouts (greater than $1 \mathrm{sec}$ in duration) was strongly correlated with measures of overall activity ( $r \mathrm{~s}>.80)$, because mice generally ran in bouts. The longest bout duration was correlated most strongly with the number of bouts greater than $10 \mathrm{sec}$ in duration $(r=.57)$, probably because they were confounded to some degree. The pattern of correlations between run- ning variables indicated that measures were influenced most by the overall activity level of the mouse.

The $\mathrm{CC}$ sizes in this sample ranged from 0 to $1.092 \mathrm{~mm}^{2}$, with the sample including 20 mice with a normal $\mathrm{CC}$ (Figure 1A) and 10 mice with complete absence of the CC (Figure 1B). The distribution of CC sizes was bimodal (see Figure 2) and the range of sizes in the normal CC group was comparable to the sizes for normal strains of mice. Only 3 of the mice exhibited partial HC deficits. Regarding morphological variables, only body weight and sex were significantly related $(t=$ $-4.416, p<.001$; males were heavier than females). There was no relationship between sex and brain size, $\mathrm{CC}$ size, or HC size ( $t$ tests; $p \mathrm{~s}>.05$ ). Brain weight was uncorrelated with $\mathrm{CC}$ or $\mathrm{HC}$ size (Spearman $r_{\mathrm{s}}=.06$ and .03 , respectively) because of the severe deficits in these structures in several of the animals. Correlations between behavioral and morphological variables are summarized in Table 3 . These correlations were generally low $(-.33<r<.32)$ and were all within the $95 \%$ confidence interval of $\rho= \pm 0.35$ (two-tailed). Because $\mathrm{CC}$ area was bimodally distributed in this sample, the results for CC size and sex were verified with $t$ tests. Overall, morphological features of the mice were generally not related to each other or to aspects of mouse wheel running.

Although simple Pearson correlations revealed no obvious effects of $\mathrm{CC}$ agenesis on wheel running, small effects might nevertheless have been present but obscured by complex relations with other variables. Therefore, a series of multiple regression analyses was examined. The dependent measure of behavior was either the average value of the variable over the 7 days or the slope of the change in behavior over the 7 days. Predictors included body weight, brain weight, $\mathrm{CC}$ area, $\mathrm{HC}$ area, and sex. Because sex and body weight were substantially correlated, the body size variable was centered by taking the difference between each mouse's body weight and the mean weight for its sex, thereby eliminating any correlation between sex and the index of body weight. The analysis was conducted according to the backward stepwise procedure. As an exploratory step, those predictors 

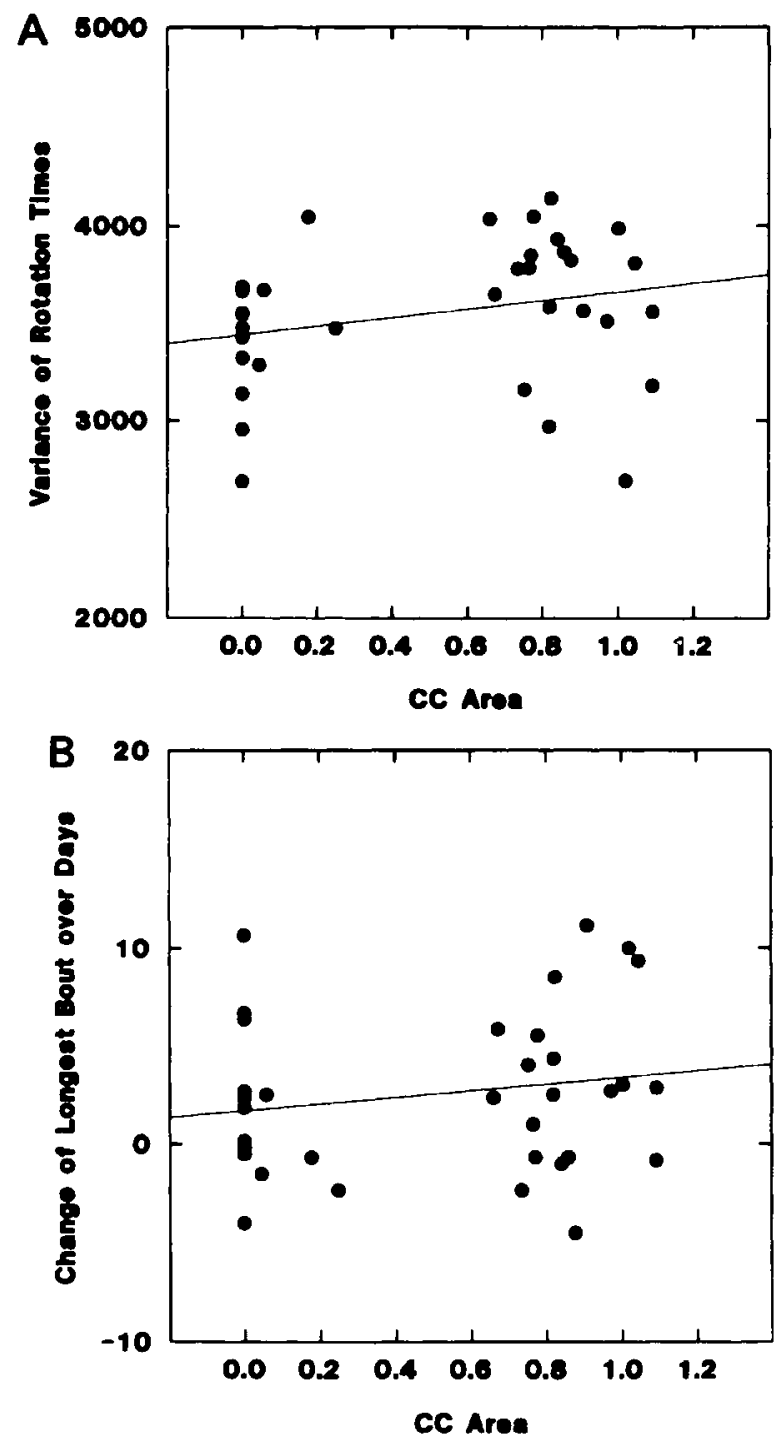

Figure 2. (A) Variability of mtation times versus cross-sectional area of the corpus callosum $\left(\mathrm{mm}^{2}\right)$ at the midsagittal plane showing the line of best fit $\left(r^{2}=.06\right)$. (B) Slope of the longest bout across days versus cross-sectional area of the corpus callosum $\left(\mathrm{mm}^{2}\right)$ at the midsagittal plane showing the line of best fit $\left(r^{2}=.03\right)$.

for which $p<.15$ were identified and examined (see Table 4). Such a liberal criterion was used to search for possible relationships with $\mathrm{CC}$ agenesis that warranted further investigation. The results suggested that females tended to run a little longer and faster than male mice, that heavier mice tended to run faster and more smoothly, and that $\mathrm{CC}$ area was weakly related to two measures of wheel running (see Figure 2 for plots of these variables against CC size). Because none of the $p$ values for the CC size effects met conventional criteria for significance, the relationship between running performance and $\mathrm{CC}$ size was examined by combining the predictive effects of these two running measurements in a discriminant analysis. $\mathrm{CC}$ area was transformed into a categorical variable (area < $.60 \mathrm{~mm}^{2}=1$; area $>.60 \mathrm{~mm}^{2}=2$ ), and a discriminant analysis on CC area using the variability of rotation times and the slope of the longest bout was performed. The resulting discriminant function [categorized $\mathrm{CC}$ area $=$ 0.939 (variability of rotation times) +0.682 (slope of the longest bout)] classified the data correctly in $71 \%$ of the cases $(24 / 34)$, a level significantly greater than chance $(z=2.64, p=.008$; two-tailed). However, this function indicated that the running speeds of animals with normal CCs varied more than those of acallosals, counter to the expectation that greater connectivity between the hemispheres should have resulted in better bilateral motor coordination. That is, although a function incorporating two measures of running-wheel performance (the variability of rotation times and the longest bout of running) predicted $\mathrm{CC}$ deficiency with moderate accuracy, examination of the meaning of the relationships suggested that the result was probably spurious.

The statistical significance of any effect of $\mathrm{CC}$ absence on running-wheel behavior was not established by these data. Although the null hypothesis of no relation could not be accepted, it was apparent that any effect must have been quite small. For the dichotomized measure of CC size, the strength of effect (estimated $\omega^{2}$ ) on behavior was .08 for average variability of rotation times and .03 for change in the longest bout. A much larger sample would be required to detect such small effects with adequate power. On the other hand, changes in running behavior over days were more substantial (estimated $\omega^{2}=.13$ and .19 for variability of running times and longest bout, respectively). Any effect of $\mathrm{CC}$ absence on running-wheel behavior must have been considerably smaller than changes in behavior over several days.

\section{DISCUSSION}

In this study, we examined voluntary running-wheel performance in a sample of adult mice with heterogeneity of CC size. Most mice ran voluntarily and some for long periods of time even on the 1st day of testing, suggesting that the apparatus evoked an ecologically valid motor behavior. Over 7 days of repeated testing, mice became more proficient at this task, running faster and longer. Agenesis of the $\mathrm{CC}$ was weakly associated with 2 of 20 measures of wheel running (decreased variability of rotation times and shorter maximum running bout duration). Although these variables were marginally good predictors of $\mathrm{CC}$ deficiency in a discriminant analysis, examination of the meaning of the relationships suggested that they might be spurious. The lack of a substantial correlation between agenesis of the $\mathrm{CC}$ and motor deficits is important for the identification of behavioral correlates of the targeted genes in transgenic mice. Tests requiring motor activity, such as those commonly used to assess spatial learning in mice, would have to be modified if motor deficits were present (Goldowitz \& Koch, 1986). 
Table 3

Correlations (Pearson $\boldsymbol{r}$, With Probabilities) Between Anatomical Measures and Mean Measures of Running-Wheel Performance*

\begin{tabular}{|c|c|c|c|c|c|c|c|c|c|c|}
\hline & \multicolumn{2}{|c|}{$\begin{array}{c}\text { Body } \\
\text { Weight }\end{array}$} & \multicolumn{2}{|c|}{$\begin{array}{l}\text { Brain } \\
\text { Weight }\end{array}$} & \multicolumn{2}{|c|}{$\mathrm{CC}$ Area $\dagger$} & \multicolumn{2}{|c|}{ HC Area } & \multicolumn{2}{|c|}{ Sext } \\
\hline & $r$ & $p$ & $r$ & $p$ & $r$ & $p$ & $r$ & $p$ & $r$ & $p$ \\
\hline Rotation & -.19 & .28 & -.03 & .87 & .05 & .78 & .21 & .24 & -.33 & .05 \\
\hline Time & -.16 & .36 & .01 & .97 & .14 & .43 & .25 & .15 & -.33 & .06 \\
\hline Swings & -.03 & .89 & .32 & .07 & .01 & .94 & -.05 & .78 & -.20 & .26 \\
\hline Minimum rotation time & -.19 & .28 & -.19 & .28 & .03 & .86 & -.13 & .48 & .05 & .80 \\
\hline Modal rotation time & -.13 & .48 & -.21 & .24 & .13 & .47 & -.07 & .70 & .16 & .38 \\
\hline Variability of rotation times & -.16 & .36 & -.23 & .19 & .25 & .16 & -.01 & .97 & .12 & .50 \\
\hline Bouts $<1 \mathrm{sec}$ & .12 & .49 & .08 & .64 & .19 & .27 & -.05 & .80 & -.13 & .47 \\
\hline Bouts $1-10 \mathrm{sec}$ & .02 & .92 & .01 & .96 & .15 & .40 & .19 & .28 & -.20 & .26 \\
\hline Bouts $>10 \mathrm{sec}$ & -.26 & .14 & -.02 & .93 & .05 & .78 & .24 & .18 & -.30 & .09 \\
\hline Longest bout & -.22 & .22 & .19 & .28 & -.03 & .85 & .25 & .16 & -.31 & .07 \\
\hline
\end{tabular}

*Two-tailed $p$ values. †Significance verified using $t$ tests.

Difficulty in detecting behavioral correlates of $\mathrm{CC}$ agenesis in mice is not surprising in cases of incomplete agenesis, because the anatomical studies of Olavarria, Serra-Oller, Yee, and Van Sluyters (1988) show that in mice with even a small $\mathrm{CC}$, the pattern of cortical connections through the $\mathrm{CC}$ is normal, only reduced in density. Absence of behavioral consequences in complete $\mathrm{CC}$ absence may indicate that the $\mathrm{CC}$ is not functionally equivalent in mice and humans or that neural plasticity may compensate more completely for the $\mathrm{CC}$ absence in mice than humans. Behavioral compensation, as suggested in the human literature on CC absence, is not likely for mice on a running wheel that evokes a rather stereotypical motor pattern: extensive observation has revealed no marked peculiarities in acallosal mice. Bilateral representation of functions as a mode of compensation has generally been rejected in humans, because most acallosal humans exhibit normal lateralization for handedness and language functioning (Sauerwein \& Lassonde, 1994); but this could be more important in

Table 4

Multiple Regression Analysis of the Mean and Slope of Running Behaviors Over 7 Days of Testing

\begin{tabular}{|c|c|c|c|c|}
\hline Running Variable & Predictor & $\begin{array}{c}\text { Standardized } \\
\text { Coefficient }\end{array}$ & $p^{*}$ & $\begin{array}{c}\text { Adjusted } \\
R^{2} \\
\end{array}$ \\
\hline \multicolumn{5}{|c|}{ Analysis of Variable Means } \\
\hline Rotations & $\operatorname{sex}$ & -.33 & .054 & .084 \\
\hline Swings & brain & .32 & .070 & .071 \\
\hline Time running & $\operatorname{sex}$ & -.33 & .061 & .078 \\
\hline Minimum rotation time & $--\dagger$ & & & \\
\hline Modal rotation time & $\begin{array}{l}\text { sex } \\
\text { body }\end{array}$ & $\begin{array}{r}.38 \\
-.36\end{array}$ & $\begin{array}{l}.091 \\
.108\end{array}$ & .046 \\
\hline Variability of rotation times & $\begin{array}{l}\text { body } \\
\text { sex } \\
\text { CC area }\end{array}$ & $\begin{array}{r}-.43 \\
.42 \\
.31\end{array}$ & $\begin{array}{l}.050 \\
.057 \\
.073\end{array}$ & .116 \\
\hline Bouts $<1 \mathrm{sec}$ & $\begin{array}{l}\text { sex } \\
\text { body }\end{array}$ & $\begin{array}{r}-.33 \\
.33\end{array}$ & $\begin{array}{l}.144 \\
.147\end{array}$ & .022 \\
\hline Bouts $1-10 \mathrm{sec}$ & -- & & & \\
\hline Bouts $>10 \mathrm{sec}$ & sex & -.30 & .088 & .060 \\
\hline Longest bout & $\operatorname{sex}$ & -.31 & .072 & .069 \\
\hline \multicolumn{5}{|c|}{ Analysis of Variable Slopes } \\
\hline Rotations & $\begin{array}{l}\text { sex } \\
\text { body }\end{array}$ & $\begin{array}{r}-.50 \\
.35\end{array}$ & $\begin{array}{l}.024 \\
.103\end{array}$ & .101 \\
\hline Swings & brain & .26 & .145 & .036 \\
\hline $\begin{array}{l}\text { Time running } \\
\text { Minimum rotation time }\end{array}$ & $\begin{array}{l}-- \\
--\end{array}$ & & & \\
\hline Modal rotation time & $\mathrm{HC}$ area & .34 & .052 & .085 \\
\hline Variability of rotation times & $\mathrm{HC}$ area & .28 & .109 & .049 \\
\hline Bouts $<1 \mathrm{sec}$ & -- & & & \\
\hline Bouts $1-10 \mathrm{sec}$ & -- & & & \\
\hline Bouts $>10 \mathrm{sec}$ & -- & & & \\
\hline Longest bout & $\begin{array}{l}\mathrm{HC} \text { area } \\
\mathrm{CC} \text { area }\end{array}$ & $\begin{array}{r}-.29 \\
.28\end{array}$ & $\begin{array}{l}.126 \\
.137\end{array}$ & .044 \\
\hline
\end{tabular}

*Two-tailed. ${ }^{\dagger}$ No significant predictors. 
mice. Evidence for the increased use of other interhemispheric pathways is mixed. The anterior commissure $(\mathrm{AC})$ is not enlarged when the $\mathrm{CC}$ is reduced or absent in BALB/c mice (Schmidt \& Caparelli-Dáquer, 1989; Wahlsten \& Jones, 1983), and CC axons do not reroute via the AC when they fail to cross (Olavarria et al., 1988; Ozaki et al., 1987; Wahlsten \& Jones, 1983). However, a recent study has found that there are approximately 70,000 more unmyelinated $\mathrm{AC}$ axons in acallosal mice than in normal controls (Livy, Schalomon, \& Wahlsten, 1995). Therefore, it is possible that connectivity between the hemispheres may be increased in cases of CC agenesis through increased number and density of $\mathrm{AC}$ axons without rerouting of $\mathrm{CC}$ axons. Compensation for $\mathrm{CC}$ agenesis may also occur through the increased use of ipsilateral motorsensory pathways (Lassonde, 1986), which may be more effective in mice than in humans because the axon pathways are shorter in the smaller mouse brain.

Although gross motor behavior may not reveal any noteworthy effects of agenesis in mice, studies of more complex movements or the development of motor control may find deficits. Motor coordination of limbs in locomotion is organized primarily by networks of spinal interneurons and may not require the participation of cortical structures. However, improvement with experience and learning suggests that wheel running may be partially activated and modulated by higher motor centers in the cortex. Because acallosal human children are often developmentally delayed in acquiring motor skills or have poor motor coordination at a young age ("Matthew's Story," 1991), examination of mouse motor development may prove interesting. Reflex development in mice is genetically variable (Wahlsten, 1975) but is not affected by CC absence (Wahlsten, 1984). Neither is asymmetry of reflex development influenced by agenesis of the CC in BALB/cCF mice (Laroche \& Ward, 1992). However, examination of the development of more complex motor movements, such as grooming (Coscia \& Fentress, 1993), may prove interesting.

\section{REFERENCES}

Aicard, J., \& Chevrie, J. J. (1994). The Aicardi syndrome. In M. Lassonde \& M. A. Jeeves (Eds.), Callosal agenesis: A natural split brain? (pp. 7-17). New York: Plenum.

Andermann, F., \& Andermann, E. (1994). The Andermann syndrome: Agenesis of the corpus callosum and sensorimotor neuropathy. In M. Lassonde \& M. A. Jeeves (Eds.), Callosal agenesis. A natural split brain? (pp. 19-26). New York: Plenum.

Bulman-Fleming, B., Wainwright, P. E., \& Collins, R. L. (1992). The effects of early experience on callosal development and functional lateralization in pigmented BALB/c mice. Behavioural Brain Research, 50, 31-42.

Coscia, E. M., \& Fentress, J. C. (1993). Neurological dysfunction expressed in the grooming behavior of developing weaver mutant mice. Behavior Genetics, 23, 533-541.

Goldowitz, D., \& KoCH, J. (1986). Performance of normal and neurological mutant mice on radial arm maze and active avoidance tasks. Behavioral \& Neural Biology, 46, 216-226.

Gruber, D., WaAnders, R., Collins, R. L., Wolfer, D. P., \& LipP, H.-P. (1991). Weak or missing paw lateralization in a mouse strain (I/LnJ) with congenital absence of the corpus callosum. Behavioural Brain Research, 46, 9-16.
Kraemer, H. C., \& ThiemanN, S. (1987). How many subjects? Statistical power analysis in research. Newbury Park, CA: Sage.

LAROCHE, L., \& WARD, R. (1992). Early behavioral asymmetry in $\mathrm{BALB} / \mathrm{cCF}$ mice showing anomalies of the corpus callosum. Comptes Rendus de l'Academie des Sciences-Serie III: Science de la Vie, 314, 559-563.

LASSONDE, M. (1986). The facilitory influence of the corpus callosum on intrahemispheric processing. In F. Lepore, M. Ptito, \& H. H. Jasper (Eds.), Two hemispheres-one brain: Functions of the corpus callosum (pp. 335-350). New York: A. R. Liss.

LipP, H.-P., BeChel, C., Wolfer, D. F., \& SCheffrahn, H. (1991) Variations in size of corpus callosum, eye color and hippocampal mossy fibres: Their relations to swimming navigation learning of mice. Third IBRO World Congress of Neuroscience Abstracts, 169.

LIPP, H.-P., \& WAANDERS, R. (1990). The acallosal mouse strain I/Ln: Behavioral comparisons and effects of cross-breeding. Behavior Genetics, 20, 728-729.

LIPP, H.-P., \& WAHLSTEN, D. (1992). Absence of the corpus callosum In P. Driscoll (Ed.), Genetically defined animal models of neurobehavioral dysfunction (pp. 217-252). Boston: Birkhauser.

Livy, D. J., Schalomon, M., \& Wahlsten, D. (1995). An increase in anterior commissure axon numbers in acallosal mice. Society for Neuroscience Abstracts, 21, 797.

Matthew's story (1991, April 26). Maine Perspective, 2(36), 4-6.

McClearn, G. E., Wilson, J. R., \& Meredith, W. (1970). The use of isogenic and heterogenic mouse stocks in behavioral research. In G. Lindzey \& D. D. Theissen (Eds.), Contributions to behaviorgenetic analysis: The mouse as a prototype (pp. 3-22). New York: Appleton.

Müller, U., Cristina, N., Li, Z.-W., Wolfer, D. P., LipP, H.-P., Rülicke, T., Brandner, S., Aguzzi, A., \& Weissmann, C. (1994). Behavioral and anatomical deficits in mice homozygous for a modified $\beta$-amyloid precursor protein gene. Cell, 79, 755-765.

Olavarria, J., Serra-Oller, M. M., Yee, K. T., \& Van Sluyters, R. C. (1988). Topography of interhemispheric connections in neocortex of mice with congenital deficiencies of the callosal commissure. Journal of Comparative Neurology, 270, 575-590

Ozaki, H. S., Murakami, T. H., Toyoshima, T., \& Shimada, M. (1987). The fibers which leave the Probst's longitudinal bundle seen in the brain of an acallosal mouse: A study with the horseradish peroxidase technique. Brain Research, 400, 239-246.

Ozaki, H. S., \& ShImada, M. (1988). The fibers which course within the Probst's longitudinal bundle seen in the brain of a congenitally acallosal mouse: A study with the horseradish peroxidase technique. Brain Research, 441, 5-14.

OzAKI, H. S., \& WAHLSTEN, D. (1993). Cortical axon trajectories and growth cone morphologies in fetuses of acallosal mouse strains. Journal of Comparative Neurology, 336, 595-604.

Qiu, M.-S., Anderson, S., Meneses, J., Pedersen, R., \& Rubenstein, J. L. R. (1995) . Emx-1 mutant mice exhibit abnormal cortical development. Society for Neuroscience Abstracts, 21, 793.

Sauerwein, H. C., \& Lassonde, M. (1994). Cognitive and sensorimotor functioning in the absence of the corpus callosum: Neuropsychological studies in callosal agenesis and callosotomized patients. Behavioural Brain Research, 64, 229-240.

Schmidt, S. L., \& Caparelli-Dáquer, E. M. (1989). The effects of total and partial callosal agenesis on the development of morphological brain asymmetries in the $\mathrm{BALB} / \mathrm{cCF}$ mouse. Experimental Neurology, 104, 172-180.

SChmidt, S. L., Manhães, A. C., \& de Moráes, V. Z. (1991). The effects of total and partial callosal agenesis on the development of paw preference performance in the BALB/cCF mouse. Brain Research, 545, 123-130.

Schmued, L. C. (1990). A rapid, sensitive histochemical stain for myelin in frozen brain sections. Journal of Histochemistry \& Cytochemistry, 38, 717-720.

Silver, P. H., \& JeEves, M. A. (1994). Motor coordination in callosal agenesis. In M. Lassonde \& M. A. Jeeves (Eds.), Callosal agenesis: A natural split brain? (pp. 207-219). New York: Plenum.

SPERRY, R. W. (1982). Some effects of disconnecting the cerebral hemispheres. Science, 217, 1223-1226.

Stumpo, D. J., Bock, C. B., Tuttle, J. S., \& Blackshear, P. J. (1995). 
MARCKS deficiency in mice leads to abnormal brain development and perinatal death. Proceedings of the National Academy of Sciences, 92, 944-948.

WAHLSTEN, D. (1975). Genetic variation in the development of mouse brain and behavior: Evidence from the middle postnatal period. Developmental Psychobiology, 8, 371-380.

WAHLSTEN, D. (1984). Growth of the mouse corpus callosum. Developmental Brain Research, 15, 59-67.

WAHLSTEN, D. (1992). The problem of test reliability in genetic studies of brain-behavior correlation. In D. Goldowitz, D. Wahlsten, \& R. E. Wimer (Eds.), Techniques for the genetic analysis of brain and behavior (pp. 407-422). Amsterdam: Elsevier.

WAHLSTEN, D., BISHOP, K., \& KRUYER, A. (in press). Calibration of computer-monitored running wheels with adjustable drag. Behavior Research Methods, Instruments, \& Computers.

WAHLSTEN, D., \& JoNes, G. B. (1983). Structural changes in brains of mice with agenesis of the corpus callosum. Society for Neuroscience Abstracts, 9, 494.
WAHLSTEN, D., \& OZAKI, H. S. (1994). Defects of the fetal forebrain in acallosal mice. In M. Lassonde \& M. A. Jeeves (Eds.), Callosal agenesis: A natural split brain? (pp. 125-133). New York: Plenum.

WAHLSTEN, D., \& Sparks, V. (1995). New recombinant inbred strains expressing $100 \%$ total absence of the corpus callosum. Society for Neuroscience Abstracts, 21, 796.

Ward, R., Tremblay, L., \& Lassonde, M. (1987). The relationship between callosal variation and lateralization in mice is genotypedependent. Brain Research, 424, 84-88.

WISNIEWSKI, K. E., \& JERET, J. S. (1994). Callosal agenesis: Review of clinical, pathological and cytogenetic features. In M. Lassonde \& M. A. Jeeves (Eds.), Callosal agenesis: A natural split brain? (pp. 1-6). New York: Plenum.

(Manuscript received September 1, 1995; revision accepted for publication March 28, 1996.) 